\title{
Perspectives and Challenges of Italian Catalogue of Herbage Varieties
}

\author{
Maurizio Giolo ${ }^{1,2}$, Stefano Macolino ${ }^{2}$, Nora Mugueta Moreno ${ }^{1}$, Renzo Torricelli ${ }^{3}$ and Mario Falcinelli ${ }^{3}$ \\ 1. Council for Agricultural Research and Economics CREA SCS, S. Giovanni Lupatoto (VR) 37057 and Milan 20133, Italy \\ 2. Department of Agronomy, Food, Natural Resources, Animals, and Environment, University of Padova, Legnaro (PD) 35020, Italy \\ 3. Department of Agricultural, Food and Environmental Sciences, University of Perugia, Perugia 06121, Italy
}

\begin{abstract}
In Mediterranean countries forage crops and temporary grasslands are the most important supply even if severe moisture stress is common. In Italy, forage systems are various and differently located from North to South of the mainland due to strong influence by rainfall distribution. Grasses and grazing cover 3.4 million ha of Italian utilized agricultural area (UAA) while alternated grassland and grass meadows cover 1.9 million ha. Most of grasslands are located in hilly and mountainous areas and are important for reducing erosion. Italy has a great longitudinal extension which accounts for a great variety of climate systems and soils: the northern regions have a humid subtropical climate and differ greatly from the south part that fits the Mediterranean climate profile. During the last 100/150 years the Italian climate has become warmer and drier showing an increase of erratic precipitation intensity. The future of breeding of forage grasses and legumes should be focused on higher nutrient use efficiencies and increased sustainability. New applications of genomics and bioinformatics will allow advanced breeding strategies. Over the past 15 years breeders have displayed a constant interest in forage species while a greater interest has risen in turfgrass varieties. Seed production of Italian herbages does not cover the requirements of the market. More specific value for cultivation and use (VCU) tests might be an effective means to improve the screening of candidate varieties. The goal is the selection of varieties able to withstand the stress of climate change, have better water and nitrogen use efficiency and resilience of vegetation cover.
\end{abstract}

Key words: Herbage varieties catalogue, herbage, varieties, DUS, VCU, climate change, low-input.

\section{Italian Forage Systems}

In North West Europe, grassland represents the main source of nutrients for livestock while in Mediterranean countries forage crops and temporary grasslands are the most important supply [1]. In fact grassland productivity in Europe is strongly correlated with annual rainfall but much less with annual temperature sum and with growing season length [2]. The European grasslands with the lowest productivity are located in the Mediterranean area, where severe moisture stress is common [2]. In Italy, forage systems are various and differently located from North to South of the mainland, due to strong influence by rainfall distribution and water availability [3]. The Usable Agricultural Area (U.A.A.), amounts to

Corresponding author: Renzo Torricelli, Ph.D., research field: plant breeding.
$12,856,048$ ha (42\% of the total national territory) and $46 \%$ of the U.A.A. is concentrated in five regions (Fig. 1): Sicily, Apulia, Sardinia, Emilia Romagna and Piedmont [4].

Most of forage crops species found in Italy belong to Leguminosae and Graminaceae families. The legumes can be grouped into annual and perennial. Grasses and grazing cover $26.7 \%$ of Italian U.A.A in the amount of 3,434,073 ha while alternated grassland and grass meadows cover 1,917,850 ha [4]. Alfalfa, which is the most important legume annual forage, covers 771,188 ha (2003-2004) [5]. In Italy, in the period 2000-2007 there was an increase in land under alternated grassland and grass meadow with respect to U.A.A. from about 1.5 million ha in 2000 to about 1.8 million in 2007. Most of grasslands are located in hilly and mountainous areas and are important for reducing erosion, regulating water regimes and for 


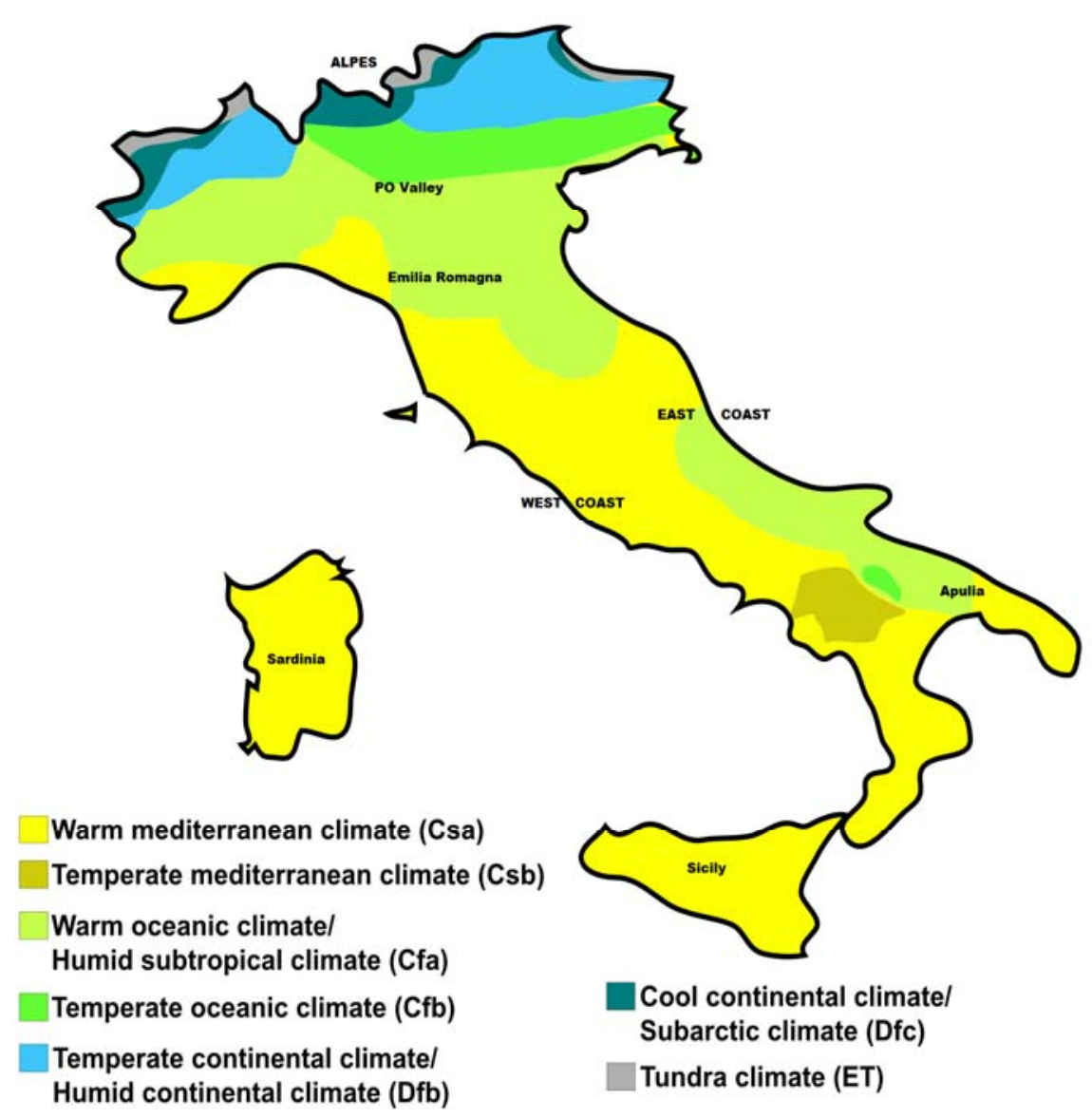

Fig. 1 Italy map of Köppen climate classification (modified). By Ali Zifan (enhanced, modified, and vectorized). (Derived from World Koppen Classification.svg.) [11] https://upload.wikimedia.org/wikipedia/commons/9/95/Italy_map_of_K\%C3\%B6ppen_climate_classification.svg.

supporting biodiversity [2]. The presence of farms with permanent grassland is an important indicator that shows agricultural areas of high nature value [6]. Grasslands appear fundamental for livestock agriculture and for delivering ecosystem services, even though their productivity is low [7, 8].

Italy ranks sixth place in the world (including conversion) for organic farming U.A.A., it is preceded only by Spain in Europe. Italy is one of main organic producers and it is ranked first in the world with regard to organically grown UAA on the total utilized area (10.8\%). The Usable Agricultural Area for organic herbages and fodder plants covers 200.887 ha and organic farming is mainly spread among sheep and goats (approximately 11\%, 2014), cattle 4.2\%, poultry $2.1 \%$ and pigs $0.6 \%$. For all livestock sectors there has been a steady increase in the number of animals in organic farming [9].

\section{Climate and New Trends}

Italy has a great longitudinal extension (between latitudes $36^{\circ}$ and $47^{\circ} \mathrm{N}$ ), which accounts for a great variety of climate systems and soils (Figs. 1 and 2). The northern regions bordering four European countries differ greatly from the southernmost part surrounded by the Mediterranean Sea. Hot and dry summers and severe winters characterize the inland northern area of Italy known as Po Valley which has a 


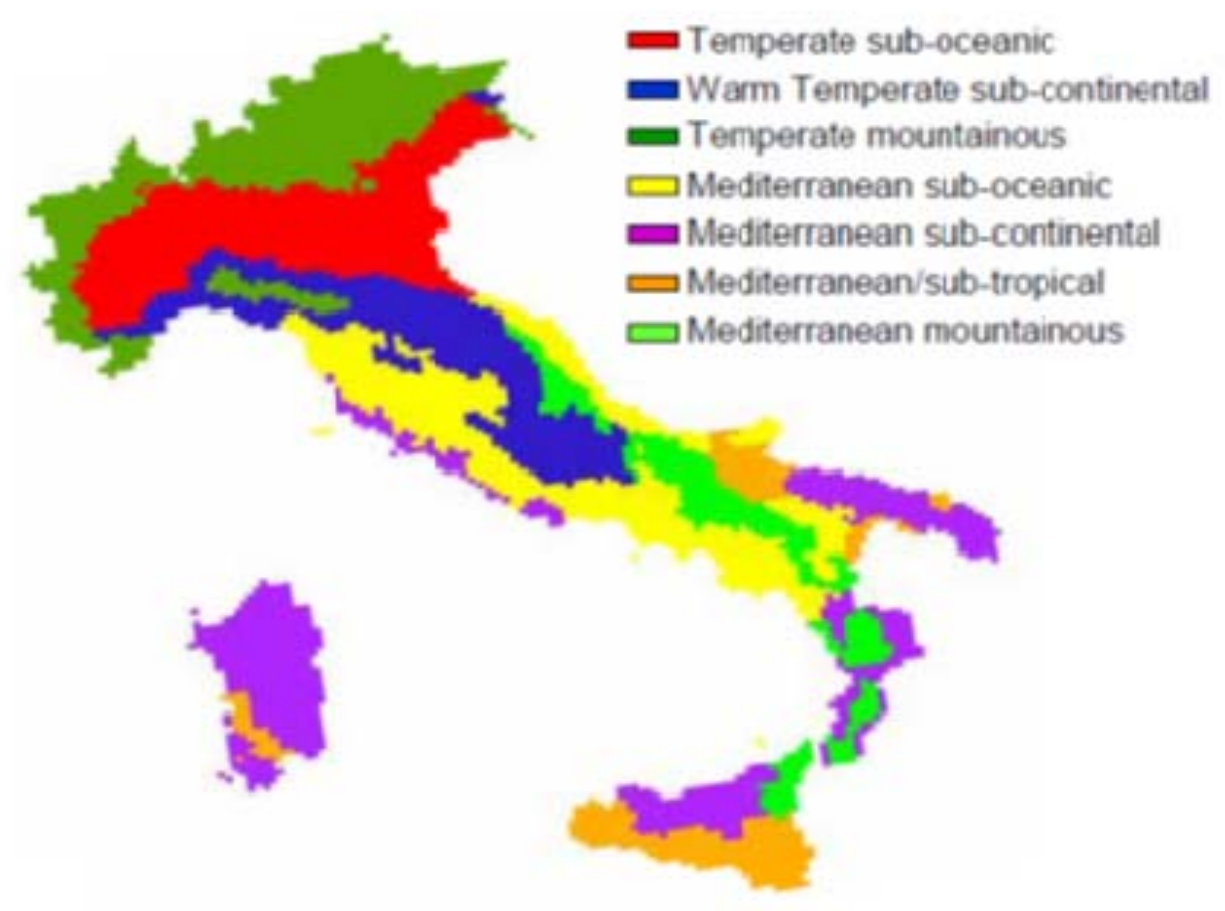

Fig. 2 Map of the climatic regions of Italy, obtained by reworking the classified climate from CNCP (National Center for Pedological Cartography) at 8 km (http://www.soilmaps.it/ita/downloads.html) [10].

Humid subtropical climate (Köppen climate classification Cfa), while the west coast of the peninsula usually fits the Mediterranean climate profile (Csa). The east coast is not as wet as the west coast, but it is usually colder in winter $[10,11]$.

The average yearly rainfall in Italy is about 1,000 $\mathrm{mm} /$ year, while the European mean is of $650 \mathrm{~mm} /$ year, but only a limited portion is utilized because of the irregular distribution in different areas and over the year [12]. Furthermore, precipitations decrease from the northern areas, where they are more evenly distributed during the year, to the southern regions where the summer is drier. Due to climate changes, a great impact is caused by the reduction in the rainfall trends and on water availability even if the Italian irrigated area covers about $20 \%$ of the total cultivated area [4]. Studies by Martiniello [13] displayed that irrigation is the most important agronomic factor increasing the period of crop utilization, the seed yield and to stabilize production in Mediterranean areas.

During the last 100/150 years the Italian climate has become warmer and drier; wet days have decreased but erratic precipitation intensity shows a positive trend [14]. Climate change can influence crop production in two different ways: extreme events can damage the crop and long-term changes can influence crop production [15]. Recent studies confirm that high concentrations of $\mathrm{CO}_{2}$ can stimulate photosynthesis and plant productivity [16]. Understanding of the phenomenon and modifying root architecture and turnover may increase Carbon sequestration in temperate grasslands [17].

The wide variability of environmental conditions and forage systems has led to the inclusion of many species suited to different environments in the National List.

\section{Future Scenarios and Breeding Role}

The future of agricultural land use in Italy and in Europe is probably unpredictable even though it will be strongly influenced by the productivity of crops, which in turn depends on changes in climatic 
conditions, atmospheric $\mathrm{CO}_{2}$ concentration and technological development, which is considered the most important driver [18]. Unfortunately in terms of harvested dry matter yield, the genetic gain of forage crops obtained by breeding is assessed about $4 \%$ decade $^{-1}$ compared to $13.5 \%$ decade $^{-1}$ of grain crops [19] even if, as reported by Humphreys [19], the comparison of total annual yield might not be substantial in marginal situations where stress tolerance is fundamental.

The future of breeding of forage grasses and legumes should be focused on higher nutrient use efficiencies, increased sustainability through lower fertilizer inputs and reduction in the agricultural footprint. EU has legislated on the subject through the Nitrates Directive and the Water Framework Directive on water quality and nitrate pollution to support clean technologies [17]. Moreover genomics offers new opportunities to improve crop yield, quality and stability of forage crops. The application of genomics and bioinformatics allows advanced breeding strategies and can increase resilience of major crops to climate variability and increase the productivity of minor crops [20]. In any case what is of major concern for the future is how different forage systems compare with other systems for human food production (agriculture) and what is the pattern for change in land use to satisfy the growing demand of food [21].

Seed production of temperate forage species will be another important target for forage breeding in the near future. It is well known that the ability to produce seed is crucial for the commercial success of a newly selected herbage cultivar. Progress in forage breeding for seed production is influenced by many factors: species, genetic diversity within species, environmental and stress factors. Seed marketing demand and cultural practices too can have an impact. Seed setting and development, and seed shattering are the qualities to be considered in breeding programs to increase seed yield [22]. Seed production of forage species in Italy is not very consistent and largely insufficient to cover national demand [23]. European forage seed production is concentrated mainly in Denmark, the Netherlands, Great Britain and France [24]. According to Danish Seed Council statistics, as reported by Wong [25], the principal European countries producing grass/legume seeds are Denmark, followed by Germany, the Netherlands, and France. French production is focused on legume seed and the ryegrasses. Italy is the other major EU nation involved with legume seed production [25]. The situation of seed for turfgrass amenity is well-known: Italy imports significant quantities of seed selected in the countries of Northern Europe which are oriented, for climatic reasons, to microthermal species although about two-thirds of our peninsula appears suited to warm grasses [26].

\section{Italian Catalogue: Trends, Seed Production and Organic Seed}

The Italian catalogue of herbage varieties is included in the Italian Catalogue of agricultural plant species set up by Law n 1096 of 1971 . The catalogue is updated yearly in accordance with the provisions of Directive 2002/53/EC on the Common Catalogue of varieties of agricultural plant species. Varieties are accepted only if they are distinct, stable and sufficiently uniform (DUS); they must be of satisfactory value for cultivation and use (VCU) [27]. This value is based on: yield, resistance to harmful organisms, response to the environment, quality characteristics. Candidate varieties are tested in field and laboratory to verify they meet the required standards [28, 29]. Variety registration is a precondition for the certification of seed. Varieties of seed covered by Council Directive 2002/53/EC can be freely marketed within the Community once they have been published in a National List and in the Common Catalogue. The National Catalogue of Herbage Varieties (updated to 6th July 2016) includes 834 varieties, of which 178 are grasses (forage), 381 are legumes and other species (annual and perennial) and 
275 are turfgrasses.

Over the past 15 years breeders have displayed a constant but limited interest in forage species, while a greater interest has risen in turfgrass varieties as shown by the number of new entries of turfgrass varieties into the Italian Catalogue (Figs. 3 and 4). The number of new varieties for herbages has remained stable, while there has been a downward trend during recent years for Mediterranean legumes and especially for alfalfa (Fig. 5), even if there is broad interest in their use in low-input oriented agriculture and for non-productive purposes such as erosion control, soil organic matter improvements, etc. [24]. Alfalfa is the main legume perennial forage crop of Mediterranean environments in northern and central Italy. Landrace material, commonly used in the past, compared with improved varieties, showed a not significant trend towards higher seed yield [30] and confirmed in accord with Falcinelli [31] the limited attention generally paid to increasing seed yield by European alfalfa breeders. As a matter of fact seed is considered of secondary importance and farmers often produce their seed directly even if its yield is extremely variable [32].

Seed production of Italian herbages does not cover the requirements of the market and breeding of many minor species with limited markets is less profitable, while seed imports are huge [23]. Furthermore, landraces and seed replacement are widespread in several areas. As shown above, during recent years the interest in the organic farming system has increased, even though the sector is facing difficulties in applying Community legislation (EU) which requires the use of organic seed. Use of seeds or other means of ensuring plant propagation in accordance with organic principles is effectively required by Annex X of Regulation (EC) No. 889/2008 [33]. Data from CREA SCS confirm the growth in the amount of seed requested for derogation for use of conventional seed from 3,960 $t$ in 2004 to 9,315 $t$ in 2009, while the trend has stabilized during recent years, except for the sharp decline in 2013, reaching 8,013 $\mathrm{t}$ in 2015 (Fig. 6). CREA SCS is the official body that coordinates and conducts DUS and VCU tests and grants derogations for conventional seed on behalf of the Ministry of Agriculture, Food and Forestry Policies

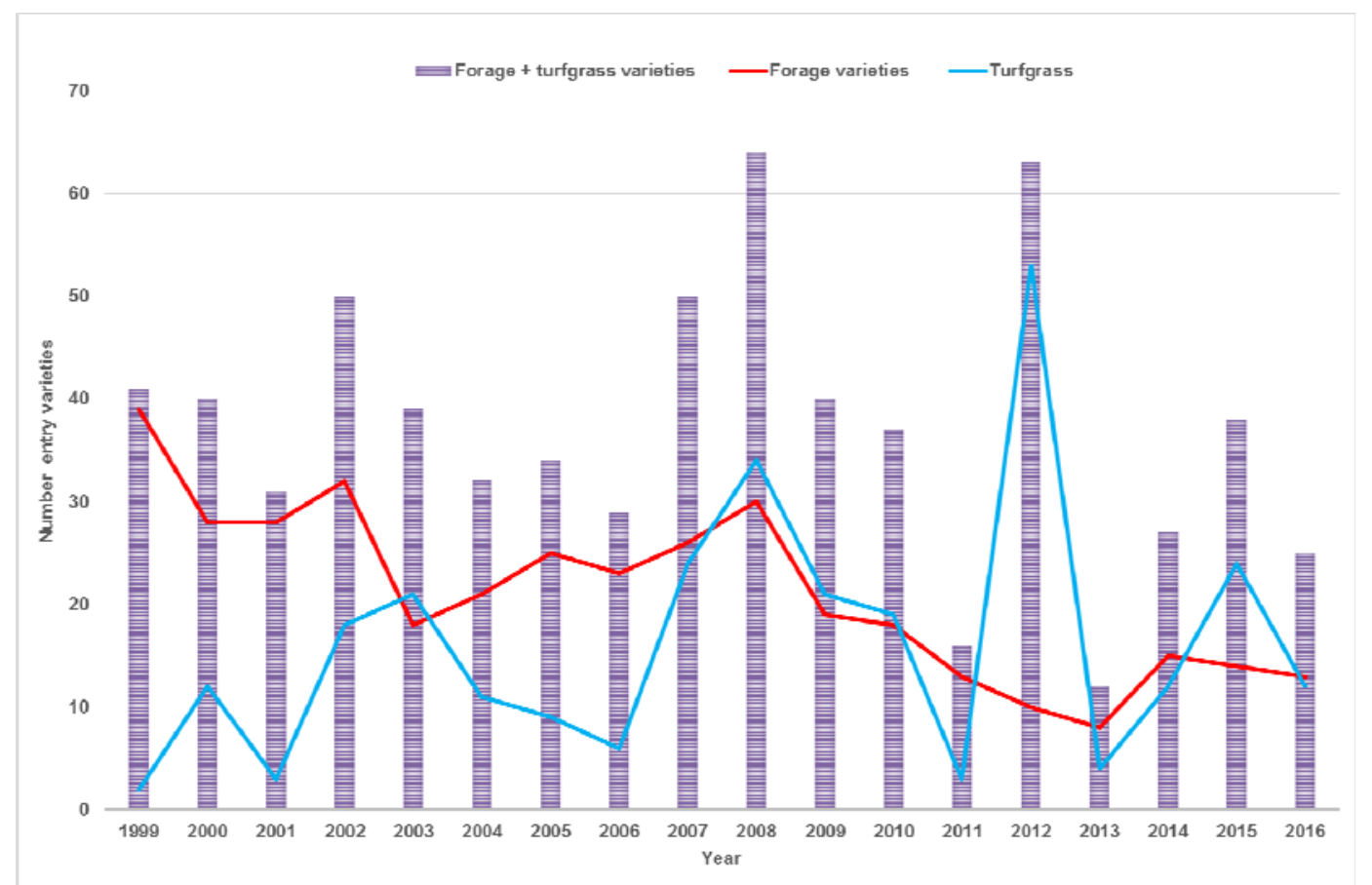

Fig. 3 Italian catalogue of herbages (1999-2016): comparison of both forage varieties and turfgrass varieties with number of total entry varieties over years. 


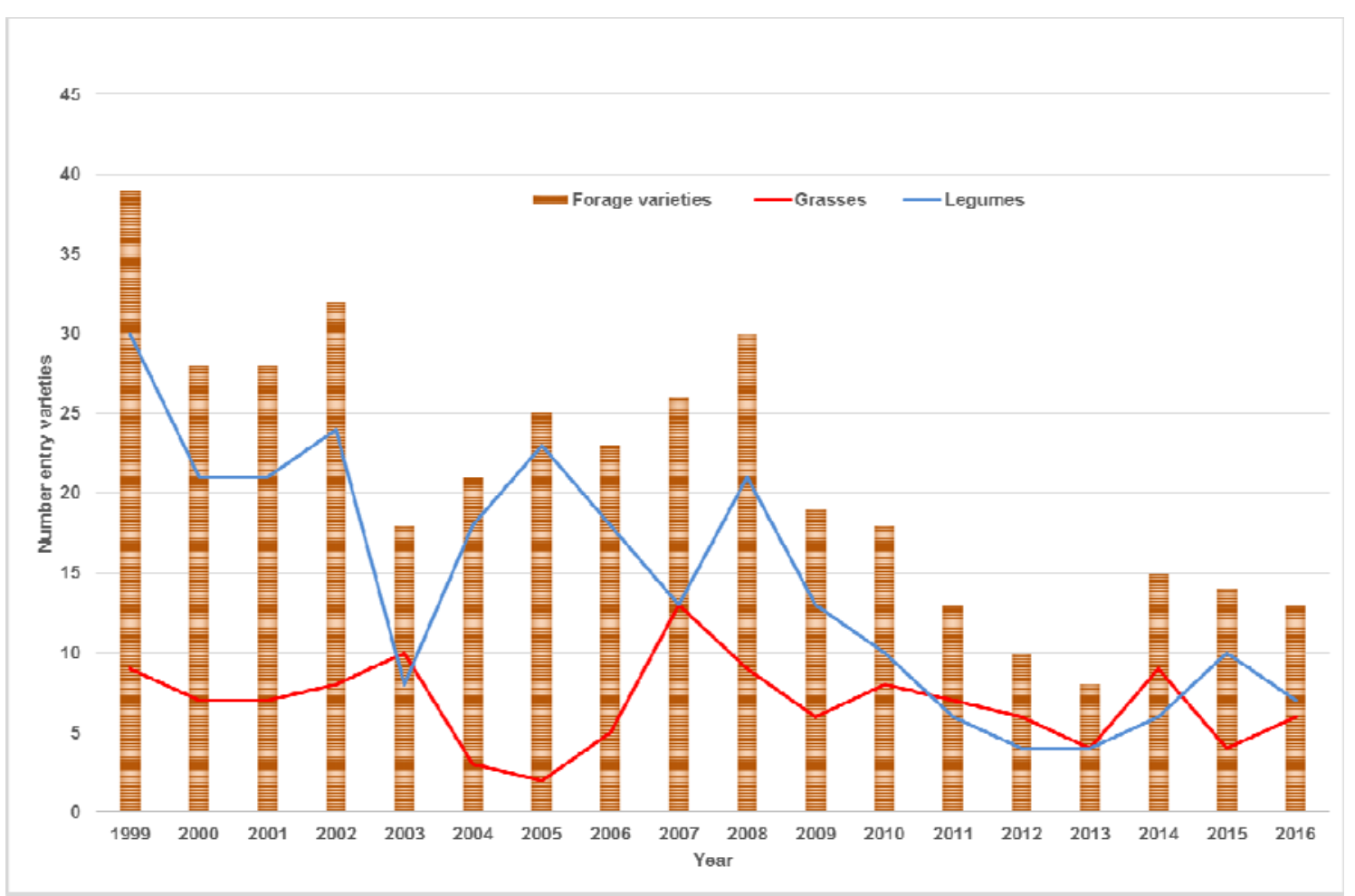

Fig. 4 Italian catalogue of herbages (1999-2016): number of entry forage varieties split into grasses and legumes varieties (forage) over years.

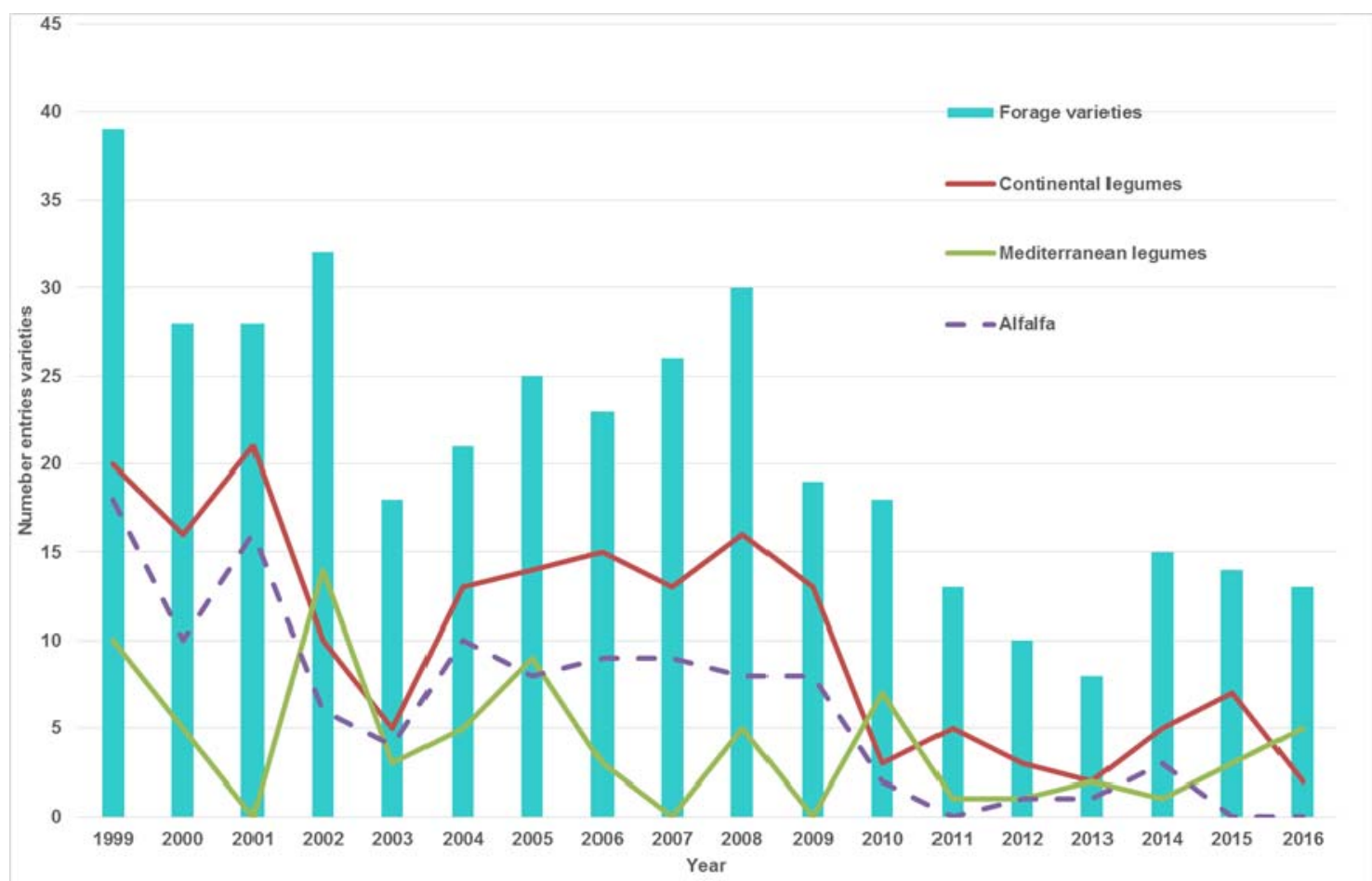

Fig. 5 Italian catalogue of herbages (1999-2016): comparison between number entry varieties of alfalfa with total entry varieties of legumes (forage) over years. 


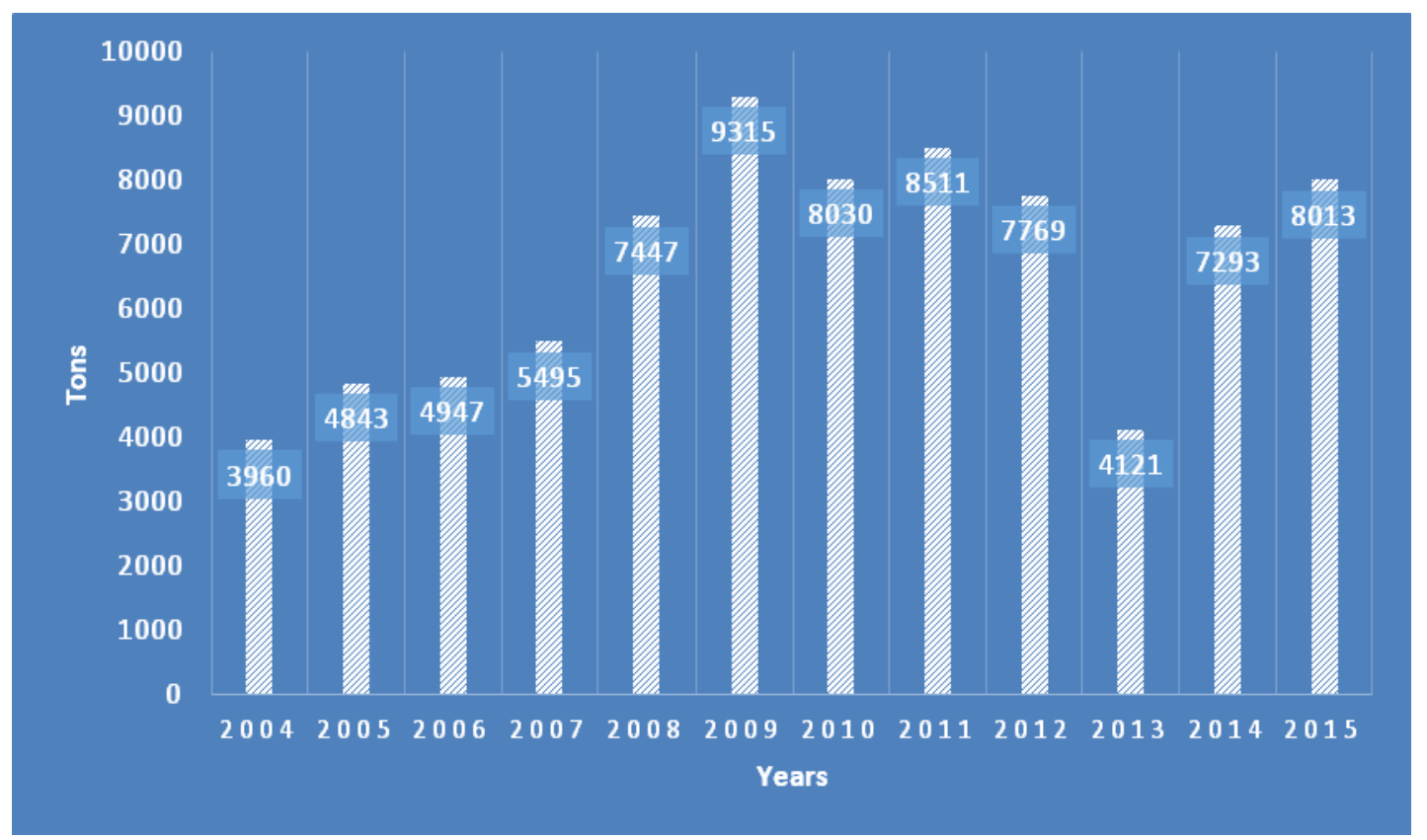

Fig. 6 Tons of forage and turfgrass seed granted yearly in derogation for conventional seed in Italy (2004-2015), data CREA SCS (the overwhelming majority is forage seed).

(MIPAAF). The network of field trials for VCU includes seven locations spread from the north to the south of the peninsula for the purpose of evaluating adaptation level of species (e.g., perennial species with persistence problems).

\section{Conclusion: Future Targets}

The spread of advanced genomic techniques could allow the use of marker-based distinctness, which can be assessed at low cost and without interactions with testing conditions and in the near future they might substitute for morpho-physiological distinctness in varietal registration schemes [34]. Moreover a bigger role for the National list of varieties as a filter of environmental adaptation of candidate varieties will be crucial. More specific VCU tests and protocols oriented towards a cleaner way to produce forage and seed might be an effective means to improve the screening of candidate varieties. The goal is the selection of varieties able to withstand the stress of climate change, have better water and nitrogen use efficiency and resilience of vegetation cover. In accordance with Fess et al. [35], a shift of research targets and plant breeding objectives from high-performance agriculture at high-energy input to those with lower fertilizer inputs is certainly desirable. This will also lead to a rationalization of the objectives even in the breeding activity with plans focused on reducing energy demands for crop production while ensuring high quality of the harvest and good yield.

\section{References}

[1] Lee, J. 1988. "Forages.” Livestock Production Science 19: 13-46.

[2] Smit, H. J., Metzger, M. J., and Ewert, F. 2008. "Spatial Distribution of Grassland Productivity and Land Use in Europe.” Agricultural Systems 98: 208-19.

[3] Pecetti, L., Annicchiarico, P., Battini, F., and Cappelli, S. 2009. “Adaptation of Forage Legume Species and Cultivars under Grazing in Two Extensive Livestock System in Italy.” Eurup. J. Agronomy 30: 199-204.

[4] ISTAT-Istituto Nazionale di Statistica. 2010 "6th General Census of Agriculture 2010.” 24 October 2010-Rome Italy. (6 ${ }^{\circ}$ Censimento generale dell'agricoltura 2010).

[5] Bteich, M. R., Solfanelli, F., and Zanoli, R. 2007. "Proteincrops in Italy." Università Politecnica delle Marche Dipartimento di Ingegneria Informatica, Gestionale e dell'Automazione "Maurizio Panti” (Le colture proteiche in Italia).

[6] Ministero delle politiche agricole, forestali ed alimentari 
(MIPAF). "The Atlas on Sustainable Agricultural Practices. The Database of Territorial Indicators of the National Rural Network as a Tool for Development, Monitoring and Evaluation of Rural Development Policies." 2011. http://www.reterurale.it/flex/cm/pages/ServeBLOB.php/L /IT/IDPagina/5512. (L'atlante ambiente sulle pratiche agronomiche ecosostenibili. Il database degli indicatori territoriali della rete Rurale nazionale come strumento per lo sviluppo, il monitoraggio e la valutazione delle politiche di sviluppo rurale).

[7] Abberton, M. 2011. "New Opportunities for Forage Grasses.” (Institute of Biological, Environmental and Rural Sciences-IBERS). Report published March 30, 2011, by Agriculture and Horticulture Development Board (AHDB) UK.

[8] C.R.P.A. "Objectives and Priorities Actions for Research and Experimentation Identified by the Inter-Regional Network for Agricultural Research, Forestry, Aquaculture and Fishing." Conferenza delle Regioni e delle Provincie autonome, 2010. Rome (Years 2010-2012). (Obbiettivi ed azioni prioritarie di ricerca e sperimentazione individuate dalla rete interregionale per la ricerca agraria, forestale, acquacoltura e pesca).

[9] CSConfagricoltura. "Organic Farming in Italy.” 2016. p. 9. (Agricoltura biologica in Italia). http://napoli.confagricoltura.it/ita/notizie/news-5/l-agricol tura-biologica-in-italia--rapporto-del-csc.

[10] Simoniello, T., Lanfredi, M., Liberti, M, Coppola, R., and Macchiat, M. 2008. "Estimation of Vegetation Cover Resilience from Satellite Time Series." Hydrol. Earth Syst. Sci. 12: 1053-64.

[11] Wikipedia. 2016. See link: https://en.wikipedia.org/wiki/Climate_of_Italy.

[12] Natali, F., Dalla Marta, A., Orlando, F., and Orlandini, S. 2009. "Water Use in Italian Agriculture: Analysis of Rainfall Patterns, Irrigation Systems and Water Storage Capacity of Farm Ponds." Italian Journal of Agrometeorology (3): 56-9.

[13] Martiniello, P. 1998. "Influence of Agronomic Factors on the Relationship between Forage Production and Seed Yield in Perennial Forage Grasses and Legumes in a Mediterranean Environment.” Agronomie 18: 591-601.

[14] Brunetti, M., Buffoni, L., Mangianti, F., Maugeria, M., and Nanni, T. 2004. "Temperature, Precipitation and Extreme Events during the Last Century in Italy.” Global and Planetary Change 40: 141-9.

[15] Moonen, A. C., Ercoli, L., Mariotti, M., and Masoni, A. 2002. "Climate Change in Italy Indicated by Agrometeorological Indices over 122 Years.” Agricultural and Forest Meteorology 111: 13-27.

[16] Soussana, J. F., and Luscher, A. 2007. "Temperate
Grasslands and Global Atmospheric Change: A Review.” Grass and Forage Science 62: 127-34.

[17] Abberton, M. T., Marshall, A. H., Humphreys, M. W., Macduff, J. H., Collins, R. P., and Marley, C. L. 2008. "Genetic Improvement of Forage Species to Reduce the Environmental Impact of Temperate Livestock Grazing Systems.” Advances in Agronomy 98: 311-55.

[18] Ewerta, F., Rounsevellb, M. D. A., Reginsterb, I., Metzgera, M. J., and Leemans, R. 2005. "Future Scenarios of European Agricultural Land Use I. Estimating Changes in Crop Productivity.” Agriculture, Ecosystems and Environment 107: 101-16.

[19] Humphreys, M. O. 1997. "The Contribution of Conventional Plant Breeding to Forage Crop Improvement.” In Proceedings of the 18th International Grassland Congress. Winnipeg, Manitoba, Canada, 71-8.

[20] Abberton, M., Batley, J., Bentley, A., Bryant, J., Cai, H., Cockram, J., Costa de Oliveira, A. C., Cseke, L. J., Dempewolf, H., De Pace, C., Edwards, D., Gepts, P., Greenland, A., Hall, A. E., Henry, R., Hori, K., Howe, G. T., Hughes, S., Humphreys, M., Lightfoot, D., Marshall, A, Mayes, S., Nguyen, H. T., Ogbonnaya, F. C., Ortiz, R., Paterson, A. H., Tuberosa, R., Valliyodan, B., Varshney, R. K., and Yano, M. 2015. "Global Agricultural Intensification during Climate Change: A Role for Genomics.” Plant Biotechnol. J. doi: 10.1111/pbi.12467.

[21] Parsons, A., Rowarth, J., Thornley, J., and Newton, P. 2011. "Primary Production of Grasslands, Herbage Accumulation and Use, and Impacts of Climate Change. Grassland Productivity and Ecosystem Services.” Edited by Lemaire, G., Hodgson, J., and Chabbi, A. ISBN 9781845938093. DOI 10.1079/9781845938093.0000.

[22] Falcinelli, M. 1999. "Temperate Forage Seed Production.” Journal of New Seeds 1 (1): 37-66.

[23] Torricelli, R., and Falcinelli, M. 2012. International Herbage Seed Group. Newsletter. Number 47: 3-5.

[24] Porqueddu, C., Ledda, L., and Roggero, P. P. 2000. "Role of Forage Legumes and Constraints for Forage Legume Seed Production in Mediterranean Europe.” In Legumes for Mediterranean Forage Crops, Pastures and Alternative Uses, edited by Sulas, L. Zaragoza: CIHEAM, 453-60. (Cahiers Options Méditerranéennes; n. 45). 10. Meeting of the Mediterranean Sub-Network of the FAO-CIHEAM Inter-Regional Cooperative Research and Development Network on Pastures and Fodder Crops, 2000/04/04-09, Sassari (Italy). http://om.ciheam.org/om/pdf/c45/00600242.pdf.

[25] Wong, D. 2005. "World Forage, Turf and Legume Seed Markets.” See link: http://www1.agric.gov.ab.ca/\$department/newslett.nsf/pd f/fsu6885/\$file/worldforage.pdf. 
[26] Severmutlu, S. Mutlu, N., Shearman, R. C., Gurbuz, E., Gulsen, O., Hocagil, M., Karaguzel, O., Hengmoss, T., Rirordan, T. P., and Gausson, R. E. 2011. "Establishment and Turf Qualities of Warm-Season Turfgrasses in the Mediterranean Region.” Hort Tech. 21: 67-81.

[27] Council of the European Union. "COUNCIL DIRECTIVE 2002/53/EC of 13 June 2002 on the Common Catalogue Of Varieties of Agricultural Plant Species.” Official Journal of the European Communities L 1931-11.

[28] Giolo, M., Mugueta Moreno, N., and Losi, M. 2010. "The Catalogue of Herbages Prepares Registration with the New Criteria.” Dal Seme 2 (V): 26-35. (Il Registro foraggere si prepara all'iscrizione con i Nuovi Criteri).

[29] MIPAAF. "Modification of Criteria and Technical Procedures for Registration in the National Catalogue of Varieties of Forage and Turfgrass Species.” Decreto 22 febbraio 2012-G.U. n. 82 del 6-4-2012-Suppl. Ord. N. 70. (Modifica dei Criteri e procedure tecniche per l'iscrizione al Registro Nazionale di varietà dispecie ad uso foraggero e da tappeto erboso).

[30] Annicchiarico, P., Pecetti, L., and Romani, M. 2007.
"Seed Yielding Ability of Landraces of Lucerne in Italy." Grass and Forage Science 62: 507-10.

[31] Falcinelli, M. 2000. "Temperate Forage Seed Production: Conventional and Potential Breeding Strategies." International Herbage Seed Production Research Group Newsletter 31: 7-15.

[32] Falcinelli, M., and Martiniello, P. 1998. "Forage Seed Production in Italy.” J. Appl. Seed Prod. 16: 61-6.

[33] Weissenberger, J. 2015. "Organic Production and the European Union.” EPRS-European Parliamentary Research Service. PE 548.989 ISBN 978-92-823-6578-6 doi: 10.2861/488634.

[34] Annicchiarico, P., Nazzicari, N., Ananta, A., Carelli, M., Wei, Y., and Brummer, E. C. 2016. "Assessment of Cultivar Distinctness in Alfalfa: A Comparison of Genotyping-by-Sequencing, Simple-Sequence Repeat Marker, and Morphophysiological Observations.” Plant Genome Volume 9 (2): 1-12.

[35] Fess, T. L., Kotcon, J. B., and Benedito, V. A. 2011. "Crop Breeding for Low Input Agriculture: A Sustainable Response to Feed a Growing World Population.” Sustainability 3: 1742-72. 